\title{
ANALISIS STRUKTUR KALIMAT IMPERATIF DALAM FILM
}

\section{"THE CAPTAIN"}

\author{
Cintiawinata Jung; Julina \\ Program Studi Bahasa Mandarin \\ Fakultas Ilmu Budaya Universitas Sumatera Utara \\ E-mail: cintiawinata99@gmail.com; julina@usu.ac.id
}

\begin{abstract}
Abstrak
Penggunaan kalimat imperatif tentunya sangat banyak ditemukan dalam film. Film sebagai karya seni berupa rangkaian gambar hidup yang diputar sehingga menghasilkan sebuah gambar bergerak yang disajikan sebagai bentuk hiburan. Penelitian ini bertujuan untuk mendeskripsikan struktur kalimat imperatif yang terdapat dalam film "The Captain". Peneliti menggunakan teori Wang tentang struktur kalimat imperatif. Metode penelitian yang digunakan adalah metode penelitian deskriptif kualitatif. Sumber data dalam penelitian ini adalah film Tiongkok tahun 2019 “The Captain” (中国机长 Zhōngguó Jīzhăng). Data penelitian ini adalah kata dan kalimat imperatif dalam film. Teknik pengumpulan data yang digunakan adalah teknik simak dan catat menurut Mahsun, selanjutnya menggunakan teknik analisis data Miles dan Huberman. Peneliti menemukan 281 kalimat imperatif dalam film "The Captain". Selanjutnya peneliti menganalisis struktur kalimat imperatif dalam film ini berdasarkan subjek, predikat dan partikel imperatifnya. Penelitian ini diharapkan dapat menjadi referensi bagi penelitian selanjutnya dan menambah wawasan pembaca tentang struktur kalimat imperatif.
\end{abstract}

Kata kunci: Kalimat Imperatif; Film Tiongkok; Film The Captain; Struktur Imperatif

\section{A. Pendahuluan}

Dalam kehidupan kita sehari-hari, kita menggunakan bahasa sebagai alat komunikasi untuk berinteraksi dengan orang-orang di sekitar lingkungan kita. Ada begitu banyak bahasa yang digunakan untuk berkomunikasi di dunia ini antara lain: Bahasa Indonesia, Inggris, Mandarin, Jepang, Arab, Perancis dan masih banyak lagi. Ilmu yang mempelajari tentang bahasa disebut linguistik. Objek kajian linguistik ialah bahasa. Bahasa menurut Kridalaksana dalam Abdul Chaer (2007:32) "bahasa adalah sistem lambang bunyi yang arbitrer 'tidak tetap', yang digunakan oleh para anggota kelompok sosial untuk berkerja sama, berkomunikasi dan mengidentifikasikan diri." Dalam hal ini, artinya bahasa tidak memiliki hubungan langsung yang bersifat wajib antara lambang dengan yang dilambangkan, sehingga bahasa merupakan hasil kesepakatan antar penutur bahasa dalam suatu masyarakat. 
Seiring dengan perkembangan perekonomian negara Tiongkok yang sangat pesat, masyarakat Indonesia tertarik untuk mempelajari bahasa negara tersebut, yakni bahasa Mandarin. Jika seseorang dapat berkomunikasi dalam bahasa Mandarin berarti orang tersebut juga mempelajari tata bahasanya. Ilmu yang mempelajari tentang tata bahasa adalah sintaksis. Menurut Kridalaksana (2001:199), sintaksis adalah cabang linguistik yang mempelajari pengaturan dan hubungan antara kata dan kata, atau antara kata dan satuan-satuan yang lebih besar, atau antar satuan yang lebih besar itu di dalam bahasa. Hal ini berarti bahwa sintaksis termasuk cabang ilmu Bahasa yang mempelajari hubungan antar satuan kata dari frasa, klausa hingga kalimat. Kalimat adalah satuan bahasa yang secara relatif berdiri sendiri, mempunyai pola intonasi akhir dan terdiri atas klausa.

Alwi (2003:353) menyatakan bahwa jenis kalimat menurut sintaksisnya terdiri atas kalimat deklaratif, kalimat interogatif, Kalimat eksklamatif dan kalimat imperatif. Kalimat deklaratif merupakan kalimat yang berbentuk pernyataan yang dapat berbentuk narasi, argumentasi, informasi atau deskripsi. Kalimat interogatif atau kalimat tanya pada dasarnya dibedakan dari tanda tanya yang menyertai kalimat tersebut. Kalimat eksklamatif isinya menyatakan perasaan kagum dan heran. Sementara itu, kalimat imperatif ditekankan sepenuhnya terhadap perintah yang titik acuannya lebih kepada objek yang dimaksud.

Peneliti memilih kalimat imperatif sebagai objek penelitian karena kalimat imperatif memiliki struktur yang beragam. Struktur kalimat imperatif ada yang menggunakan subjek, tanpa subjek, menggunakan predikat, ada yang menggunakan partikel imperatif dan tanpa partikel imperatif. Hal ini membuat peneliti tertarik untuk meneliti kalimat imperatif.

Penggunaan kalimat imperatif tentunya sangat banyak ditemukan dalam film. Film merupakan sebuah karya seni berupa rangkaian gambar hidup yang diputar sehingga menghasilkan sebuah gambar bergerak yang disajikan sebagai bentuk hiburan. Salah satunya adalah film terkenal tahun 2019 yakni film The Captain (中国机长 Zhōngguó Jīzhăng). The Captain adalah sebuah film drama Tiongkok yang disutradarai oleh Andrew Lau. Film tersebut dirilis di Tiongkok pada 30 September 2019. Penggunaan kalimat imperatif ditemukan pada dialog antar tokoh, baik itu antara pilot dengan rekan kerjanya, antar penumpang pesawat maupun antar pramugari. Film "The Captain" mengajarkan nilai moral kehidupan untuk senantiasa menghargai nyawa, menghormati pekerjaan serta mengajak para penonton untuk mematuhi peraturan yang telah dibuat. 
Menurut Koran Seruya (Desember 2019), Film tersebut diangkat berdasarkan pada insiden Sichuan Airlines Penerbangan 8633. Film ini menggambarkan salah satu pendaratan darurat paling ajaib dalam sejarah kontemporer penerbangan Tiongkok. Liu Chuanjian, seorang kapten Sichuan Airlines yang membawa 119 penumpang dan 9 awak pulang dengan selamat setelah kaca depan pesawatnya pecah dan akhirnya hancur dalam perjalanan dari Chongqing di China barat daya ke Lhasa pada tanggal 14 Mei 2018.

Berikut ini adalah beberapa contoh kalimat imperatif bahasa Mandarin yang ditemukan pada film "The Captain":
（1）保安
: 来, 可以进了。
...(Durasi 10:15)
bǎoān
: lái, kěyǐ jìnle.
Petugas Keamanan : Mari, (anda) sudah boleh masuk.

Tabel 1. Struktur Kalimat Imperatif "Penumpang Memasuki Bandara"

\begin{tabular}{|l|l|l|l|l|}
\hline 保安: & 来, & 可以 & 进 & $\begin{array}{l}\text { 了。 } \\
\text { bǎoān: }\end{array}$ \\
Petugas Keamanan: & lái, & jìn & $\begin{array}{l}\text { le. } \\
\text { mari, }\end{array}$ \\
\hline & breleh & masuk & sudah \\
\hline
\end{tabular}

Contoh (1) merupakan kalimat imperatif, Dari segi struktur dapat dilihat berdasarkan subjek dan predikat. Subjek contoh (1) dihilangkan karena mengandung arti orang kedua jamak “你们 nǐmen” (kalian). Pada bagian predikat, menggunakan dua predikat/ kata kerja “来 lái (datang, mari)” dan “进 jìn (masuk)”. Tabel 1 menunjukkan bahwa pembicara (satpam) meminta pendengar untuk melakukan dua tindakan. “来 lái (datang, mari)” sebagai tindakan pertama, pembicara (satpam) meminta pendengar (penumpang) untuk bergerak mendekatinya. Tindakan ke-2 adalah “进 jìn (masuk)”, selanjutnya meminta mereka untuk masuk.

\section{B. Metode Penelitian}

Menurut Kridalaksana (dalam Suhardi 2008: 80) Kalimat adalah satuan bahasa yang secara relatif berdiri sendiri, mempunyai intonasi final (kalimat lisan) dan secara aktual ataupun potensial terdiri atas klausa, dapat dikatakan bahwa kalimat membicarakan 
hubungan antara sebuah klausa dengan klausa yang lain. "Kalimat adalah susunan kata atau frasa berdasarkan pada aturan tata bahasa, dapat mengungkapkan makna yang lebih lengkap, menunjukkan nada dan intonasi tertentu" (Li dejin, 2012:330). Li (2012:365-402) menjelaskan tentang pembagian kalimat berdasarkan fungsinya terdiri atas 4 jenis yaitu: (1) Kalimat Deklaratif; (2) Kalimat Interogatif; (3) Kalimat Imperatif; (4) Kalimat Ekslamatif.

Film adalah gambar bergerak yang merupakan bentuk dominan dari komunikasi massa visual dibelahan dunia ini. Film atau motion pictures ditemukan dari hasil pengembangan prinsip-prinsip fotografi dan proyektor. Film adalah media komunikasi yang bersifat audiovisual untuk menyampaikan suatu pesan kepada sekelompok orang yang berkumpul di suatu tempat tertentu (Effendy, 1986: 134).

Kridalaksana (2001:199) menyatakan bahwa sintaksis adalah cabang linguistik yang mempelajari pengaturan dan hubungan antara kata dan kata, atau antara kata dan satuansatuan yang lebih besar, atau antar satuan yang lebih besar itu di dalam bahasa. Hal ini berarti bahwa sintaksis termasuk cabang ilmu bahasa yang mempelajari hubungan antar satuan kata dari frasa, klausa hingga kalimat. Kalimat adalah satuan bahasa yang secara relatif berdiri sendiri, mempunyai pola intonasi akhir dan terdiri atas klausa.

Menurut Wang (dalam Kang, 2011:18-23) pada elektrik jurnal (e-jurnal) nya yang berjudul "Grammatical Differences In Sentence Structure Between Mandarin and Modern American Standard English" mengemukakan bahwa "kalimat imperatif bahasa Mandarin dibentuk dari tiga aspek yaitu (1) penggunaan subjek di dalam kalimat; (2) penggunaan predikat (kata kerja) dalam kalimat; (3) penggunaan partikel imperatif dalam pembentukan kalimat imperatif bahasa Mandarin”. Penggunaan subjek kalimat imperatif bahasa Mandarin ada yang dapat dihilangkan dan ada yang harus muncul di dalam suatu kalimat imperatif. Subjek kalimat imperatif sering dihilangkan apabila mengandung arti orang kedua tunggal maupun orang kedua jamak yaitu “你 nǐ” (anda), “你们 nǐmen” (kalian). Menurut Wang (dalam Kang, 2011:21-23) mengungkapkan bahwa ada tujuh syarat utama pembentukan kata kerja kalimat imperatif bahasa Mandarin. Sebagian besar kata kerja kalimat imperatif bahasa Mandarin memiliki arti memerintah, memohon agar melakukan sesuatu, baik yang diinginkan maupun yang tidak diinginkan oleh pembicara. Partikel imperatif yang terdapat pada kalimat imperatif bahasa mandarin terbagi atas : partikel 请 qǐng, 要 yào, 别 bié atau 不 要 búyào, 千万 qiānwàn, 麻烦 máfan, 吧 ba dan 啊 a. 
Dalam penelitian ini menggunakan penelitian deskriptif kualitatif. Menurut Sukmadinata (2011:73), penelitian deskriptif kualitatif ditujukan untuk mendeskripsikan dan menggambarkan fenomena-fenomena yang ada, baik bersifat alamiah maupun rekayasa manusia, yang lebih memperhatikan mengenai karakteristik, kualitas, keterkaitan antar kegiatan. Sumber data penelitian ini diperoleh dari film tiongkok yakni "The Captain". Data dalam penelitian ini adalah kata dan kalimat Imperatif yang terdapat dalam Film "The Captain".

Menurut Sugiyono (2008:62) Teknik pengumpulan data merupakan langkah yang paling strategis dalam penelitian, karena tujuan utama dari penelitian adalah mendapatkan data. Dalam penelitian ini, peneliti menggunakan dua macam teknik pengumpulan data, yaitu teknik simak dan teknik catat. Teknik simak dilakukan untuk menyimak penggunaan bahasa. Istilah menyimak di sini tidak hanya terbatas pada bahasa lisan tetapi juga penggunaan bahasa secara tertulis. Teknik Catat artinya mencatat beberapa bentuk yang relevan bagi penelitian dari penggunaan bahasa tertulis (Mahsun,2005:92).

Langkah awal yang ditempuh peneliti adalah mencari sumber data dengan mengunduh film "The Captain" di internet. Selanjutnya peneliti menyimak percakapan dan menandai kata/ kalimat imperatif yang terdapat dalam film tersebut. Langkah terakhir setelah menyimak percakapan dalam film adalah mencatat kalimat imperatif yang terdapat dalam film, yang kemudian akan diklasifikasikan berdasarkan strukturnya. Teknik analisis data yang digunakan dalam penelitian ini adalah analisis kualitatif yang dikemukakan oleh Miles dan Huberman (dalam Sugiyono, 2008: 91) yakni: (1) menyimak percakapan dalam film "The Captain"; (2) menandai dan mencatat kalimat imperatif yang muncul dalam film "The Captain"; (3) mengklasifikasikan kalimat imperatif tersebut berdasarkan strukturnya; (4) menyimpulkan hasil pembahasan.

\section{Hasil dan Pembahasan}

Penelitian ini membahas tentang struktur kalimat imperatif yang ditinjau dari penggunaan subjek, predikat dan partikel imperatifnya.

\section{Struktur Kalimat Imperatif Film “The Captain"}

Kalimat Imperatif dalam film "The Captain" dapat dibentuk dari penggunaan subjek, predikat dan partikel imperatif serta sering diakhiri dengan tanda seru (!) atau tanda titik (.). Berikut data (1) dan (2) menunjukkan beberapa struktur kalimat imperatif. Secara 
keseluruhan, Subjek kalimat imperatif dalam film "The Captain" ada yang dihilangkan dan ada juga harus dituliskan. Sesuai dengan teori Wang (dalam kang, 2011:18) Peneliti menemukan subjek kalimat imperatif yang dihilangkan dalam film "The Captain" sebanyak 138 kalimat. Sedangkan subjek yang tertulis adalah sebanyak 122 kalimat.

Tabel 2. Kalimat Imperatif Berdasarkan Subjek Dalam Film "The Captain"

\begin{tabular}{|c|l|c|}
\hline No. & \multicolumn{1}{|c|}{ Jenis } & Frekuensi Penggunaan \\
\hline 1 & Subjek 你 nǐ dan 你们 nǐmen yang dihilangkan & 138 \\
\hline 2 & $\begin{array}{l}\text { Subjek yang tertulis dalam Film “The Captain” } \\
\text { (咱们 zánmen, 您 nín, Menyatakan suatu kalimat } \\
\text { perintah majemuk, kata ganti, panggilan titel, nama, } \\
\text { sapaan) }\end{array}$ & 122 \\
\hline \multicolumn{1}{|c|}{ Total } & 260 \\
\hline
\end{tabular}

Tabel 3. Kata Kerja Kalimat Imperatif Film "The Captain"

\begin{tabular}{|c|c|c|}
\hline Syarat Pembentukan & Data & Durasi \\
\hline \multirow{2}{*}{$\begin{array}{l}\text { Penambahan Kata - } \\
\text { 下/ pengulangan } \\
\text { diletakan setelah kata } \\
\text { kerja } \\
\text { (Kt kerja }+ \text { 一下 } \\
\text { /pengulangan) }\end{array}$} & 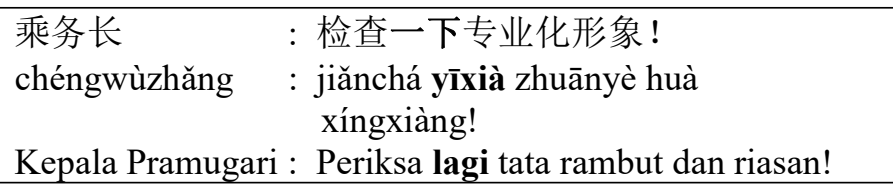 & 06.24 \\
\hline & $\begin{array}{ll}\text { 乘客 } & \text { : 姑娘你没事吧? 醒醒啊！ } \\
\text { chéngkè } & \text { : gūniáng nǐ méishì ba? xǐngxǐng a! } \\
\text { Penumpang : Nona anda tidak apa kan? bangunlah! }\end{array}$ & 47.57 \\
\hline $\begin{array}{l}\text { Penambahan kata 着 } \\
\text { zhe } \\
(\text { Kt kerja }+ \text { 着 zhe })\end{array}$ & - & - \\
\hline \multirow{3}{*}{$\begin{array}{l}\text { Penambahan } \\
\text { pelengkap ( 补语 bǔ } \\
\text { yǔ) (来 lái, 上 shàng, } \\
\text { 去 qù ) dan lain- lain) } \\
\text { (Kt kerja + 补语 bǔ } \\
\text { yǔ) }\end{array}$} & $\begin{array}{ll}\text { 乘客 } & \text { : 姑娘, 我们一起栓上吧! } \\
\text { chéngkè } & \text { : gūniáng, wǒmen yīqǐ shuānshàng ba! } \\
\text { Penumpang } & \text { : Nona, mari kita ikat bersama! }\end{array}$ & 41.22 \\
\hline & $\begin{array}{ll}\begin{array}{l}\text { 乘务员 } \\
\text { chéngwùyuán : }\end{array} & \text { 先不要起来, 在座位上坐好。 } \\
& \text { hăo. bùyào qǐlái, zài zuòwèi shàng zuò } \\
\text { Pramugari } \quad: & \begin{array}{l}\text { Jangan berdiri dulu, duduklah di tempat } \\
\text { anda. }\end{array}\end{array}$ & 01.22 .45 \\
\hline & $\begin{array}{ll}\text { 乘客 } & \text { : 乘务员, 咱们得赶紧飞回去啊！ } \\
\text { chéngkè } & \begin{array}{l}\text { : chéngwùyuán, zánmen déi gănjǐn fēi huíqù } \\
\text { a ! }\end{array} \\
\text { Penumpang : } & \text { Pramugari, kita harus segera kembali ! }\end{array}$ & 53.38 \\
\hline $\begin{array}{l}\text { Kata kerja harus } \\
\text { disertai dengan } \\
\text { subjek. } \\
\text { (Subjek+ Kt kerja) }\end{array}$ & $\begin{array}{ll}\text { 服务员 } & \text { : 请你确认! } \\
\text { fúwùyuán } & \text { : qǔng nǐ quèrèn! } \\
\text { Customer service } & \text { : mohon anda pastikan! }\end{array}$ & 18.00 \\
\hline $\begin{array}{l}\text { Kata kerja harus } \\
\text { disertai dengan objek. } \\
\text { (Kt kerja + Objek) }\end{array}$ & $\begin{array}{l}\text { : 空中的飞机帮我叫一下四川 } \\
\text { 8633。 } \\
\text { : kōngzhōng de fēijī bāng wǒ jiào yíxia } \\
\text { sìchuān } 8633 .\end{array}$ & 45.00 \\
\hline
\end{tabular}




\begin{tabular}{|c|c|c|}
\hline & $\begin{array}{c}\text { Petugas pengendali : Pesawat di udara mohon bantu saya } \\
\text { hubungi Sichuan } 8633 \text {. }\end{array}$ & \\
\hline \multirow{2}{*}{$\begin{array}{l}\text { Penambahan 状语 } \\
\text { zhuàngyǔ (跟 gēn,duì, } \\
\text { 向 xiàng) } \\
\text { (状语 zhuàngyǔ }+\mathrm{Kt} \\
\text { Kerja) }\end{array}$} & $\begin{array}{l}\text { 机长 : 来吧, 去跟乘客道个歉, 走! } \\
\text { jīzhăng : lái ba, qù gēn chéngkè dào gè qiàn, zǒu! } \\
\text { Kapten : mari, ayo kita minta maaf kepada penumpang ! }\end{array}$ & 01.38 .21 \\
\hline & $\begin{array}{l}\text { 王默 : 向军方请求支援! } \\
\text { wángmò : xiàng jūn fāng qǐngqiú zhīyuán! } \\
\text { Wangmo: Minta bantuan ke pihak militer! }\end{array}$ & 42.19 \\
\hline $\begin{array}{l}\text { Penambahan kata } \\
\text { bantu sambung 连动 } \\
\text { 词 liándòngci (去 } \\
\text { qù 、来 lái) } \\
\text { (kata bantu sambung } \\
\text { 连动词 lián dòngci + } \\
\text { kata kerja) }\end{array}$ & $\begin{array}{ll}\text { 乘务员 } & \text { : 好了之后, 去吃火锅! } \\
\text { chéngwùyuán } & \text { : hăo le zhīhòu, qù chī huǒguō! } \\
\text { Pramugari } \quad: \text { Setelah sembuh, ayo pergi makan hotpot! }\end{array}$ & 01.32 .37 \\
\hline \multirow{4}{*}{$\begin{array}{l}\text { Penambahan Partikel } \\
\text { 吧 ba }\end{array}$} & $\begin{array}{ll}\text { 乘客 } & \text { : 再拿两袋吧! } \\
\text { chéngkè } & \text { : zài ná liăng dài ba! } \\
\text { Penumpang } & \text { : ambillah dua bungkus lagi! }\end{array}$ & 30.48 \\
\hline & 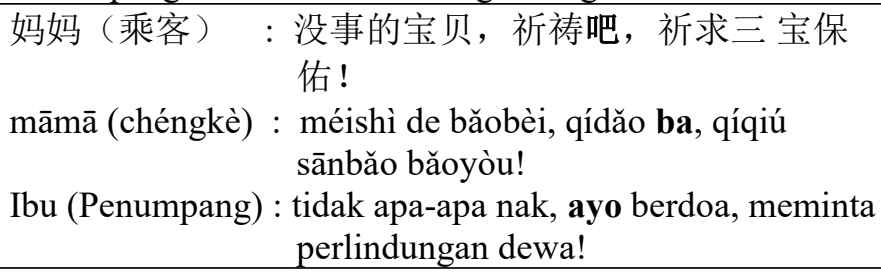 & 51.53 \\
\hline & $\begin{array}{ll}\text { 乘务员 } & \text { : 上车吧! } \\
\text { chéngwùyuán } & \text { : shàng chē ba! } \\
\text { Pramugari } & \text { : naiklah ke mobil! }\end{array}$ & 01.32 .44 \\
\hline & $\begin{array}{l}\text { 乘务员 } \quad \text { : 来, 给我吧! } \\
\text { chéngwùyuán : lái, gěi wǒ ba! } \\
\text { Pramugari } \quad \text { : mari, berikan padaku! }\end{array}$ & 01.42 .34 \\
\hline
\end{tabular}

Tabel 3 menunjukkan pembentukan kata kerja dalam film "The Captain" sangat beragam sesuai dengan teori Wang. Namun peneliti menemukan tidak ada pembentukan kata kerja imperatif dengan "penambahan kata 着 zhe (Kt kerja + 着 zhe)" dalam film “The Captain". Sesuai dengan teori wang, pembentukan kata kerja imperatif dengan penambahan kata “着 zhe” menyatakan permohonan/ meminta seseorang melakukan sesuatu tindakan/ keadaan.

Tabel 4. Partikel Imperatif Film "The Captain"

\begin{tabular}{|c|c|c|}
\hline $\begin{array}{c}\text { Partikel } \\
\text { Imperatif }\end{array}$ & Data & Durasi \\
\hline $\begin{array}{l}\text { 请 qǐng } \\
\text { "Silakan" }\end{array}$ & \begin{tabular}{|ll} 
机器 & : 请吹气！ \\
jīqì & : qǔng chuīqì ! \\
Mesin & : Silahkan hembuskan napas !
\end{tabular} & 05.26 \\
\hline
\end{tabular}




\begin{tabular}{|c|c|c|}
\hline & 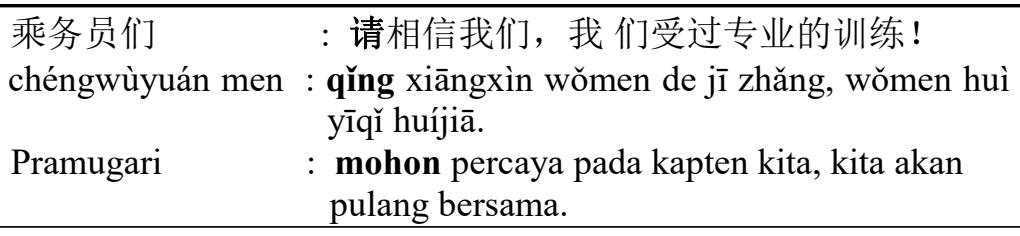 & 07.10 \\
\hline \multirow[b]{2}{*}{ 要 yào “harus" } & $\begin{array}{l}\text { 妈妈（乘客）：回家以后, 要把作业好好写完！ } \\
\text { māmāa (chéngkè) : huíjiā y̌̌hòu, yào bă zuòyè hăohăo xiěwán! } \\
\text { Ibu (penumpang) : Setelah pulang, harus kerjakan tugasmu ya! }\end{array}$ & 23.33 \\
\hline & 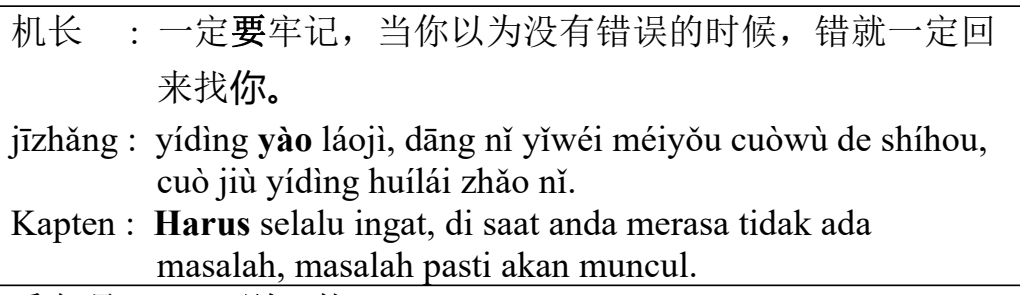 & 32.05 \\
\hline \multirow{3}{*}{$\begin{array}{l}\text { “别 bié” atau } \\
\text { “不要 bu yào” } \\
\text { artinya } \\
\text { “jangan” }\end{array}$} & $\begin{array}{ll}\text { 乘务员 } \quad \text { : 别理他! } \\
\text { chéngwùyuán : bié lǐ tā! } \\
\text { Pramugari } \quad \text { : jangan hiraukan dia! } \\
\end{array}$ & 09.15 \\
\hline & 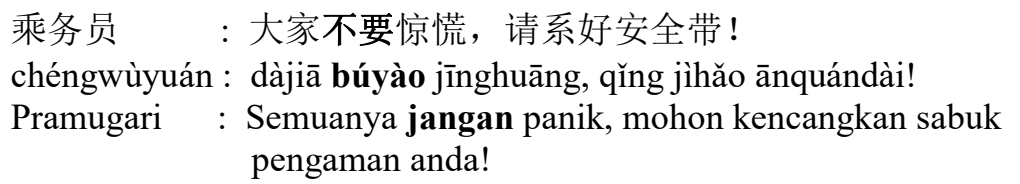 & 36.55 \\
\hline & $\begin{array}{ll}\text { 乘务长 } & \text { : 不用说话! } \\
\text { chéngwùzhăng } & \text { : búyòng shuōhuà! } \\
\text { Kepala pramugari : tidak perlu berbicara! }\end{array}$ & 01.32 .13 \\
\hline $\begin{array}{l}\text { "千万 } \\
\text { qiānwàn" } \\
\text { menyatakan } \\
\text { permohonan } \\
\text { atau nasihat. }\end{array}$ & - & - \\
\hline $\begin{array}{l}\text { “麻烦 máfan” } \\
\text { menyatakan } \\
\text { permintaan } \\
\text { terhadap } \\
\text { seseorang } \\
\text { melakukan } \\
\text { sesuatu. }\end{array}$ & $\begin{array}{l}\text { 保安 } \quad \text { 麻烦签一下字! } \\
\text { băoān : máfan qiān yíxià zi! } \\
\text { Petugas }\end{array}$ & 14.16 \\
\hline \multirow{2}{*}{ “吧 ba” } & $\begin{array}{ll}\text { 乘务员 } & \text { : 上车吧 } ! \\
\text { chéngwùyuán } & \text { : shàng chē ba! } \\
\text { Pramugari } \quad \text { : naiklah ke mobil! }\end{array}$ & 01.32 .44 \\
\hline & $\begin{array}{ll}\text { 乘务长 } & \text { : 咱们先下客吧! } \\
\text { chéngwùzhăng } & \text { : zánmen xiān xiàkè ba! } \\
\text { Kepala pramugari : ayo kita turunkan penumpang dulu! }\end{array}$ & 01.28 .27 \\
\hline \multirow[t]{2}{*}{ “啊 a” } & 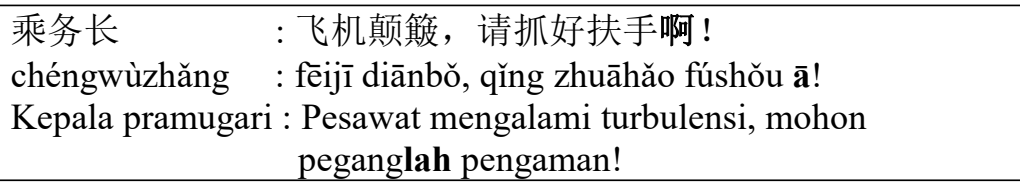 & 33.34 \\
\hline & $\begin{array}{ll}\text { 第二机长 } & \text { : 刘哥,挺住啊! } \\
\text { dì èr jīzhăng } & \text { : liúgē, tǐngzhù } \overline{\mathbf{a}} ! \\
\text { Kapten kedua }: \text { Bang Liu, bertahanlah! }\end{array}$ & 59.56 \\
\hline
\end{tabular}


Tabel 4 menunjukkan penggunaan partikel imperatif dalam film "The Captain", ada yang menggunakan partikel 请 qunng, 要 yào, 别 bié, 麻烦 máfan, 吧 ba dan 啊 a. Namun peneliti tidak menemukan adanya penggunaan partikel “千 ` qiānwàn”. Menurut Hu (2018:34) partikel “千万 qiānwàn” digunakan untuk memberikan nasihat, memiliki makna sama dengan “一定 yídìng” (harus). Partikel “千万 qiānwàn” kebanyakan digunakan pada kalimat negasi, sering diikuti dengan kata “别 bié”, “不要 búyào” dan “不能 bùnéng”. Sedangkan dalam kalimat positif sering diikuti dengan kata “要 yào”. Peneliti menemukan tidak adanya penggunaan partikel “千万 qiānwàn”, namun peneliti menemukan adanya penggunaan kata “一定 yídìng” (harus).

\section{Kesimpulan}

Peneliti menemukan 281 kalimat imperatif dalam film Tiongkok tahun 2019 "The Captain” (中国机长 Zhōngguó Jīzhăng). Struktur kalimat imperatif dalam film “The Captain" dapat ditinjau dari penggunaan subjek, predikat dan partikel imperatifnya.

Pada bagian subjek, sebagian besar dihilangkan apabila mengandung arti orang kedua tunggal maupun orang kedua jamak yaitu “你 nı̌” (anda), “你们 nǐmen” (kalian). Peneliti menemukan subjek kalimat imperatif yang dihilangkan dalam film "The Captain" sebanyak 138 kalimat. sedangkan subjek yang tertulis adalah sebanyak 122 kalimat. Selain itu, peneliti menemukan sebanyak 101 kalimat imperatif dalam film "The Captain" yang subjeknya berupa kata ganti “你 nǐ ” “anda', “你们 nǐmen” (kalian), “大家 dàjiāa”(semua orang), panggilan titel (nama pesawat Sichuan 8633, nomor panggilan setiap pramugari), nama orang dan sapaan (阿姨āyí 'ibu', 先生 xiānsheng ‘tuan’, 孩子 háizi ‘anak').

Pada bagian predikat, peneliti menemukan adanya pembentukan kata kerja kalimat imperatif sesuai dengan teori Wang. Namun, ada 1 (satu) syarat pembentukan yang tidak ditemukan dalam film ini yakni: pembentukan kata kerja imperatif dengan penambahan kata 着 zhe. Penggunaan dengan pembentukan kalimat imperatif ini terkesan kurang sopan karena Film "The Captain" menceritakan tentang pelayanan pramugari terhadap penumpang pesawat, kepercayaan diri para pramugari dalam menghadapi situasi darurat. Kata-kata yang digunakan pramugari menunjukkan rasa hormat dan kesopanan dengan menambahkan kata “请 qǔng” (mohon/ silahkan). 
Pada bagian partikel imperatif, Peneliti tidak menemukan adanya penggunaan partikel “千万 qiānwàn” (menyatakan permohonan/ nasihat) dalam film ini. Partikel ini memiliki makna sama dengan “一定 yídìng” (harus). Penggunaan “一定 yídìng” (harus) lebih banyak ditemukan dalam film ini.

\section{Daftar Pustaka}

Alwi. 2003. Tata Bahasa Baku Bahasa Indonesia (edisi ketiga). Jakarta: Balai Pustaka.

Chaer, Abdul. 2007. Linguistik Umum. Jakarta: Rineka Cipta

Effendy. 1986. Dimensi Dimensi Komunikasi. Bandung: Alumni.

Hu, 2018, Analisis Perbandingan Kalimat Imperatif dalam Fazhan Hanyu dan Hanyu Jiaocheng, Tesis, Program Pascasarjana Bahasa dan Sastra, Univ. Central China Normal, Wuhan.

IYS, 2019, Kisah Nyata Pilot Liu Chuanjian Dapat Penghargaan Rp 11 Miliar karena Selamatkan 119

Penumpang Karena Kaca Pesawat Pecah, koranseruya.com, diakses tgl 14 Mei 2020.

Jessica, 2015, Analisis Kontrastif Kalimat Imperatif Bahasa Mandarin Dalam Koran Xun Bao dan Bahasa Indonesia Dalam Koran Analisa, Skripsi, Fakultas Ilmu Budaya, Univ. Sumatera Utara, Medan.

Kang. 2011. Grammatical Difference in Sentence Structure between Mandarin and Modern American Standard English, University of Wisconsin-Platteville Seminar Paper, USA, May 5.

Kridalaksana. 2001. Kamus Linguistik. Jakarta: Gramedia Pustaka Utama

Li, Dejin. 2012. Waiguoren Shiyong Hanyu Yufa (Edisi Kedua). Beijing: Beijing Yuyan Daxue Chubanshe. Mahsun. 2005. Metode Penelitian Bahasa. Jakarta: PT Raja Grafindo Persada.

Sugiyono. 2008. Metode Penelitian Kunatitatif Kualitatif dan R\&D. Bandung: Alfabeta.

Suhardi. 2008. Sintaksis. Yogyakarta: UNY Press.

Sukmadinata. 2011. Metode Penelitian Pendidikan. Bandung: Remaja. Rosadakarya.

Catatan:

Artikel pernah dipresentasikan pada Seminar Nasional APSMI 24 Oktober 2020 